\title{
Historical Elements and National Unity of Malaysia
}

\author{
Ishak Saat, Mohd Kasri Saidon, Ahmad Zainudin Husin \& Ruhaizan \\ Sulaiman
}

To Link this Article: http://dx.doi.org/10.6007/IJARBSS/v11-i11/11556

DOI:10.6007/IJARBSS/v11-i11/11556

Received: 13 September 2021, Revised: 17 October 2021, Accepted: 30 October 2021

Published Online: 08 November 2021

In-Text Citation: (Saat et al., 2021)

To Cite this Article: Saat, I., Saidon, M. K., Husin, A. Z., \& Sulaiman, R. (2021). Historical Elements and National Unity of Malaysia. International Journal of Academic Research in Business and Social Sciences, 11(11), 569 $-581$.

\section{Copyright: (C) 2021 The Author(s)}

Published by Human Resource Management Academic Research Society (www.hrmars.com)

This article is published under the Creative Commons Attribution (CC BY 4.0) license. Anyone may reproduce, distribute, translate and create derivative works of this article (for both commercial and non-commercial purposes), subject to full attribution to the original publication and authors. The full terms of this license may be seen at: http://creativecommons.org/licences/by/4.0/legalcode

\section{Vol. 11, No. 11, 2021, Pg. $569-581$}

Full Terms \& Conditions of access and use can be found at http://hrmars.com/index.php/pages/detail/publication-ethics 


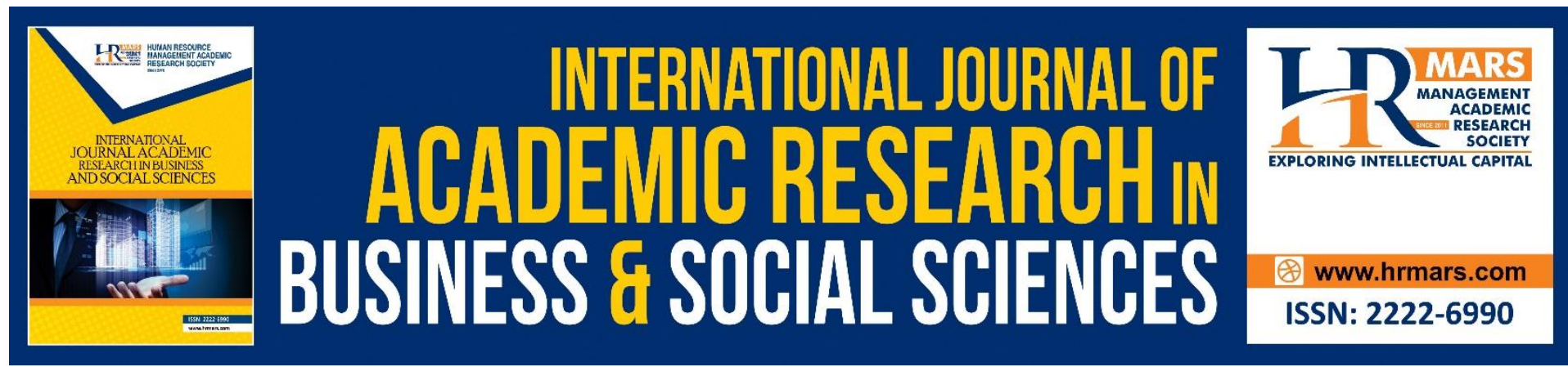

\title{
Historical Elements and National Unity of Malaysia
}

\section{Ishak Saat ${ }^{1}$, Mohd Kasri Saidon², Ahmad Zainudin Husin ${ }^{3}$ \& Ruhaizan Sulaiman ${ }^{4}$}

${ }^{1}$ Professor, History Department, Faculty of Social Science, Universiti Pendidikan Sultan Idris (UPSI), 35900 Tanjung Malim, Perak, ${ }^{2}$ Museum Director of UUM, Universiti Utara Malaysia, 06000 Sintok, Kedah, ${ }^{3}$ Associate Professor, History Department, Faculty of Social Science, Universiti Pendidikan Sultan Idris, 35900 Tanjung Malim, Perak, ${ }^{4}$ Senior Lecturer, Centre for

Fundamental Studies, Universiti Sultan Zainal Abidin (UniSZA), 21300, Kuala Nerus,

Terengganu.

Email: ishakhj@fsk.upsi.edu.my, kasri@uum.edu.my, zainuddin.husin@fsk.upsi.edu.my, ruhaizan@unisza.edu.my

\begin{abstract}
Malaysia was developed under the political concensus among the multi-racial political leader. The struggle of the founding fathers of Malaysia led to the birth of an independence nation by 31 August 1957 as Tanah Melayu and became Malaysia after the joining of Sabah, Sarawak and Singapore on 1963. This article was written to analyse the experience of the coalition of multi-racial leaders in the struggle of independence using the historical approach. The understanding on this coalition will contribute to the new approach for the next generation to appreciate the concept of multiracial coalition as a fundamental for the future of Malaysian identity. Based on unity and harmony, inter-racial relations can be nurtured and always be preserved for the sake of an independent Malaysia. Failure to understand the past will cause a nation to fall back into the arena of racial strife and riots that will not benefit but harm the country. The implication is the collapse of an independent nation that was built together. Therefore, all aspects of life, be it political, economic, and social, should be nurtured towards the success of Rukun Negara (National Principles) by appreciating the history in building a new Malaysia.
\end{abstract}

Keywords: History, Unity, Tolerance, 13 May 1969, Political Tsunami Dan Political Consensus

\section{Introduction}

Malaysia, the multiracial country consist of, various races, ethnic groups, religions, cultures, and territorial backgrounds, live peacefully as a united nation by fully committing to the national identity. Therefore, to create unity, the dynamic process to strengthen the relationship between races and states in Malaysia must be continuous. This matter aims to form a Malaysian nation with its own identity based on the Federal Constitution and Rukun Negara (National Principles). Therefore, all Malaysians are entrusted to practice inter-racial tolerance to the maximum. For Malaysia's sake, people of various races must put the 
country's interests before the interests of individuals or specific races. As such, it can ensure prosperity and cooperation between the races is always at the highest level. Thus, the new generation will always inherit this independent country in a very peaceful, prosperous, and developing state.

\section{Historical Elements of National Unity}

The foundation of harmony in a plural society lies in inter-racial tolerance. In realizing racial unity, the spirit of tolerance become an important element to ensure the wellbeing of life together in peace, freedom, and independence. Malaysia is a small country with diverse communities, rich in ethnic, culture, language, and religion diversity. The diversity that makes Malaysia becomes a model of racial harmony by the international community (Malaysia Kita, 1991). But in building a nation called Malaysia, we are often tested by various tribulations that sometimes threaten inter-racial harmony.

The prosperity of Malaysia is the result of a long historical process. The unity in Malaysia today is proof of happiness which has gone through several stages of interaction, integration, and assimilation between local indigenous and non-indigenous communities. This process took fairly a long time and has also undergone a dark period. The political consensus among the different races leader during the struggle of independence era was maintained until independence was achieved on 31 August 1957. This date is a sacred date for all Malaysians. Celebrated with glory and gratitude by all Malaysians regardless of race and religion. From there, Malaysia developed from an agrarian country to a developing country in modern technology. From the first prime minister to the fourth, the drive towards sustainable development has been well implemented and successful. Policies outlined such as the Look East Policy, Privatisation Policy, Malaysian Corporatisation Policy, Heavy Industry Policy, and various other policies towards developing Malaysia have yielded commendable results. Gratitude should be given to the father of independence and its later leaders, for example, Tunku Abdul Rahman Putra Al-Haj and his successors, in leading Malaysia towards prosperity and development. His successors include great leaders such as Tun Abdul Razak Hussein, Tun Hussein Onn, and Tun Dr. Mahathir Mohamad. The new generation must have accurate facts about the roles, contributions, and sacrifices of previous leaders so that they can understand and appreciate the pioneering path explored by previous generations. This process should be conveyed to the younger generation by none other than studying the history of Malaysia, based on the concept of as it happens (Carr, 1965). In other words, history is described objectively based on actual historical facts, not biased or prejudiced (Gawronski, 1975). The same is true of Ibn Khaldun's view, who outlined that history is a record or information about human beings, societies, figures, and civilizations. It revolves around human qualities such as friendliness, leadership, and camaraderie between one faction and another, eventually forming a nation (Ibn-Khaldun, 1962).

Through the historical process, the unity of the people of a country called Malaysia was tested. However, the people must always be reminded so that the integrity of the relationship between these races is always preserved. Here, the question arises to what extent the strength and spirit of unity among the Malaysian community are real. Sometimes the integrity of racial unity in Malaysia is threatened or disturbed by several incidents that may cause dissatisfaction among the races. To discuss the question related to this aspect, we must first reveal the history of immigrants in Malaysia. Through this history, each individual will know 
the origin of the events that have taken place. Only then can we think twice when we speak about racial sensitivity (Saat, 2005).

Malaysia is known for its ethnic diversity that lives in an atmosphere of strong consensus. This makes Malaysia a model of a plural society at the international level. The native people of Malaysia are the Malays, the indigenous and original people, but the arrival of the colonialists brought the immigrants, which diversified the ethnic Malaysian society. Over time, the nation grew and after the end of the colonial era, some of the immigrants returned to their homeland while others preferred to stay here and make Malaysia their home, and this was gracefully accepted by the Malays.

The 13 May 1969 tragedy saw bloodshed inter racial clash in Kuala Lumpur. This opened the eyes of various parties leaders about the need to preserve racial sensitivities in a plural society (Soong, 2007). As a result, the National Movement Council (MAGERAN) was established (Government White Paper, 1969). Then, on July 1, 1969, the Department of National Unity was established, as a result of the MAGERAN administration, to address the issues related to the reconstruction of a united society. This department continues to be given the responsibility to foster and preserve inter-racial unity and is currently placed under the Prime Minister's Department and is now known as the Department of National Unity and Integration (JPNIN). Various efforts are made by the government to continue to ensure national unity and this can be seen with the formation of the Barisan Nasional party, introducing the use of various national policies such as Rukun Negara and the implementation of the New Economic Policy (NEP) as well as fostering unity in the education curriculum through the National Education Philosophy (Malaysia Kita, 1991).

\section{Plural Society}

The process of interaction, integration, and assimilation took place in Malaysia, with the principle of strengthening the Bumiputera traditional cultures and retaining of some elements of immigrant cultures that are suitable for national culture development. It should be noted that culture covers all aspects of human life, which includes the social system, religion, culture, customs and arts, language, economy, education, as well as political aspects. The assimilation of the Malay culture towards the Chinese and Indian cultures must not become a spectre and pollute the political scenario since this may not be impossible. Efforts for each culture to lower these boundaries or walls must be made so that the integration process runs smoothly and the nurturing of national culture can be applied positively and effectively (Osman, 1988). Finally, the effort to produce a Malaysian nation that lives in harmony and peace will become a reality. Following the Malay proverb, 'United we stand, divided we fall.'

There are two schools of thought introduce by the political leader to create unity in Malaysia based on national identity; first, the concept of Malaysian Malaysia and second, a society that has similarities with each other. The first stream proposes that society should accept that plural society in the country needs to be preserved. Malaysia can still achieve unity even though it comprises a plural society. The second school of thought asserts that to create a united society, they must be assimilated so that a new identity, called the Malaysian race, can be formed. The process of socialisation, such as applying the same education system, using the same language, the practice of intermarriage, and the appreciation of national ideology through Rukun Negara (Rukun Negara Malaysia, 2008), can help to achieve this objective. It 
is national consciousness that needs to be nurtured, and not ethnic consciousness because if ethnic consciousness still thickens, then national consciousness will be marginalized.

After the 13 May 1969 incident, the government formulated and emphasized several policies in the socio-economic field that lead to the unity and harmony of heterogeneous society and national integration. The policies in question include the National Education Policy, National Cultural Policy, and New Economic Policy. These policies are further strengthened by the introduction of Rukun Negara as the national ideology and efforts to reduce racist political actions that can divide the people. Consequently, the Barisan Nasional coalition was born. As a follow-up action, several other policies were also formulated to complement and strengthen the efforts of forming the Malaysian nation. Among them are the National Development Policy, National Vision Policy, and National Social Policy. The government's position is clear:

"Malaysia should not only be developed in the economic field. It must be a fully developed nation in all fields: economic, political, social, spiritual, psychological, and cultural. We must progress in the sense of national and social unity, in the sense of our economy, in the sense of social justice, political stability, the system of government, quality of life, social and spiritual values, national dignity, and confidence."

(Mohamad, 1991)

Therefore, we must remember that Malaysia has gone through a bitter tragedy that has shamed the nation. Learn from history so that things that should not be questioned are not blindly spoken of. Statements that are not based on historical facts should not be abused. Do not allow narrw political and personal interests to override national interests. The effects are very painful and severe. Indeed, it is a difficult task and involves a long process to build a country but tearing it apart takes only a few seconds. Remember, history is a reminder.

\section{Leaders Who Lead}

In going through the era of change and the passage of time, human beings need a paradigm shift to think of new things to produce something more meaningful and valuable in life. The importance of citizens to become successful in various fields and aspects demands the leadership to be responsible for implementing new policies that balance national development, the wellbeing of the people, and continuous economic stability into the future. The vision to build the country should produce a developed Malaysia in the eyes of the world, without having to imitate the development glorified by the West, which takes pride in progress without considering the real meaning of human capital development. It is useless to be a developing and modern country if the trust given is not accompanied by solid integrity (Badaruddin, 2016). Indeed, history has shown that the Malay Sultanate was once a distinguished empire, which eventually collapsed because the leaders have lost their integrity. The abuse of power, money politics, corruption, injustice, waste, nepotism, and cronyism saw an end of the Malacca Sultanate King when it finally fell to the earth through the Portuguese attack. But the main cause of the collapse remains forgotten by the following generations until the bad practices keep repeating themselves. Therefore, a leader must have a big heart and put the interests of the people and the country first, following the slogan of One Malaysia, people first, performance now, not just political rhetoric (MStar, 2009). 
Development in a developing country is vital, but it is temporary. Real development and happiness must go hand in hand with the development of human capital. Plans arranged by the government to develop the people and country should be studied so that the balance between material and life demands toward harmony will produce a combination of ideas to form a conception that does not stray from the real path, where the quality of life values will ensure a balance between material and spiritual development. Thus, the country must be developed with its human capital in mind, which can be driven and implemented through the Education Development Master Plan (PIPP) (Ministry of Education Malaysia, 2006).

\section{Nation Building through the National Education Philosophy (FPK)}

"Education in Malaysia is an on-going effort towards further developing the potential of individuals in a holistic and integrated manner, so as to produce individuals who are intellectually, spiritually, emotionally and physically balanced and harmonious, based on a firm belief in and devotion to God. Such an effort is designed to produce Malaysian citizens who are knowledgeable and competent, who possess high moral standards, and who are responsible and capable of achieving high level of personal well-being as well as being able to contribute to the harmony and betterment of the family, the society and the nation at large."

(Ministry of Education, 1991)

Philosophy comes from two Greek words philo and sophic which mean philo-love and sophicwisdom. Western philosophers such as Socrates, Plato, Aristotle, and Descardes defined Philosophy: "faith that is believed". Western society makes philosophy a way of life, based on this definition.

Meanwhile, philosophy from the Islamic point of view does not stray from its original meaning, but is processed to ensure compatibility with the main source of Islam: "Love wisdom and strive to obtain it". From this definition, it is clear that philosophy from the Islamic point of view must be based on 3 main sources, namely the Qur'an, hadiths, and the consensus of scholars.

" Whoever is granted wisdom is certainly blessed with a great privilege."

(Al-Baqarah: 269)

Rasulullah SAW also said which means:

"Wisdom is the lost property of the believer, take hold of it wherever ye find it."

In terms of philosophy, education is the process of humanizing human beings, which is the process of cultivating and increasing awareness in human beings (conscientization) about the physical and metaphysical, in line with the views of Imam Al-Ghazali. (Muhamad Rumaizuddin. 2001). FPK was formed to realize the country's desire to produce individuals who can develop the country and live in harmony and cultivate love. This means that the syllabus, pedagogy, application of values, curriculum, and co-curriculum of education must be governed by a national education philosophy.

Basically, FPK emphasises the development of four main elements in an individual, namely intellectual, spiritual, emotional, and physical, to make the aspiring citizen a person who has true and strong beliefs, patriotic, knowledgeable, healthy, independent, is socially acceptable and able to control emotions wisely. At a glance, FPK seems to follow Islamic believes, namely 
the aspect of human self-development. Saidina Umar Al Khattab answered when asked by Rasulullah, what would Umar have asked if his prayer is granted? Saidina Umar replied:

"I will seek ten young men (teenagers) who are brave and smart for me to nurture to become an asset for the Muslims".

(Kandahlawi, 2019)

The National Education Philosophy will not be effective if it is not being appreciated and implemented in the culture and educational institutions. Several national issues that adorn the headlines of the press every year need answers on whether the Ministry of Education of Malaysia has realized the goals of FPK or FPK itself needs to be amended to meet the demands of a country that is increasingly developed and facing global challenges. The answer is that the implementation process must bring the meaning of education to a process of acquiring knowledge, not be exam-oriented. Remember, the collapse of a nation and civilization occurs when it forgets the responsibility in knowledge development. As a result, the society would be blind in a highly developed and sophisticated world. Remember, history is a lesson.

\section{Human Capital Development}

Human capital has been a major topic of conversation among Malaysians in the past. The concept of human capital development is given serious emphasis in line with planning towards a developed country in science and technology based on its mold and fulfilling the aspirations of Vision 2020. It is a common phenomenon that Malaysia is very good at formulating government policies but weak in terms of implementation and enforcement (Saat, 2009). In this regard, the Ministry of Education of Malaysia has prepared a blueprint, the Education Development Master Plan (PIPP), which outlines the policies, goals, and focus of human capital development during the 9th Malaysia Plan.

Tun Abdullah Ahmad Badawi stressed the importance of human capital:

"Quality human capital is a must, not a luxury.... Continuous quality education and skills training will also ensure that the country's human capital remains relevant to industry and market needs and able to face the challenges and increasing international competition."

(Badawi, 2006)

The word 'capital' means something used as a basis to expand one's assets. The second meaning is the advantage one possesses. The third meaning is something used to obtain something desired. The word 'human' means mankind. The two words, when combined, form the word 'human capital', which can be inferred as something that is used as a basis for expansion, the advantages possessed, and something that is used to achieve the desired goal. This desire can be achieved only through knowledge and education.

Education is the major contributor to the development of the social and economic capital of the country. It inspires creativity and fosters innovation that equips the younger generation with the necessary skills to compete in the labor market and is the key to overall economic development. In this regard, the Government must ensure that the country's education system functions in tandem with the New Economic Model, Economic Transformation Program, and Government Transformation Program, which form the basis of the country's economic development to compete in the global economy. 
Human Capital Development places knowledge as the main feature that needs to be emphasized in implementing and realizing a holistic, progressive, moral and world-class education system. This is in line with the teachings of Islam which places knowledge in the highest place and requires human beings to seek knowledge as a supply of life in this world and the hereafter. As ordered by God/Allah which means:

"O you who believe! When you are told to make room in gatherings, then do so. Allah will make room for you 'in His grace'. And if you are told to rise, then do so. Allah will elevate those of you who are faithful, and 'raise' those gifted with knowledge in rank. And Allah is Well-Aware of what you do."

(Al-Mujadalah: 11)

As a lesson, we can conclude that knowledge is more important than practice. Worship is not accepted without knowledge. The act of following other cultures is not encouraged by Islam. Based on this view, it can be concluded that knowledge is an invaluable capital and can develop human potential and success through the effectiveness of education and training programs that cover all aspects of life.

The Malaysian Education Development Plan is then streamlined from time to time towards strengthening the education sector because it is a major contributor to the development of social and economic capital of the country. Education also inspires creativity and fosters innovation that provides the youth with the necessary skills to compete in the labor market and is the key to overall economic development. In this regard, the government must ensure that the national education system progress in tandem with the New Economic Model, Economic Transformation Program and Government Transformation Program, which form the basis of the country's economic development to compete in the global economy. (Malaysia Education Development Plan, 2013-2025)

Religion, the human race, and the nation need Human Capital as a source of energy. The success of human capital development depends on our desires as Malaysians because we are the ones who design, colour, and shape the mold of human capital. As multi-racial Malaysians, we should be aware that the task of building human capital is not only on the shoulders of those in power but also on the shoulders of parents and society as a whole. Therefore, Malaysians must be aware and strive to develop themselves into human capital under the concept of umatan wasatan (moderation and balance). Only then will Malaysia be shaped according to its mold, able to solve any crisis independently. Vision 2020 has closed its curtain, but the building of Malaysia as a nation will continue as long as the world exists. Malaysia must be a country whose society is united, confident, possess high moral values, tolerance, and strong ethics, live democratically, cares, be fair, and have full control over a competitive economy. We must continue to learn from the greatness of world civilization, whether be it Western civilization or Islamic civilization, following the ancient expression in philosophy, 'History Teaches the Meaning of Maturity' (Saat et al., 2014)

\section{The New Malaysia Political Agenda}

The agenda to enhance the Malays and Bumiputeras economy should be the basis of any political movement. Political parties, especially, need to be educated to know the limits and boundaries so that their approaches and strategies do not harm the Malays or Bumiputeras, either in the short or the long run. Political practice must place Islamic morality as a guideline 
so that their political actions are not based solely on Machiavellian politics. But the political foundations should be centered on Islamic law following the concept of umatan wasatan or exemplary people (Shaharuddin \& Syazwanuddin, 2017). Hence, education's role in the development and progress of the Malays and Bumiputeras is very important, and not to be mislaid. The equality agenda must be seen from the perspective of local religion and culture. Therefore, more decisive efforts need to be made by those entrusted to rule. In the end, education policy needs to be maintained to produce the Malay/Bumiputera identity. (Resolution of the Malay Agenda and National Unity Conference, 2001).

At the same time, the agenda is not to ignore the non-bumiputras interest. It is only the agenda to balance the achievements between the two races. Continuous and integrated education must be based on the history of the formation of Malaysia so that the young generation of Malaysian will understand the nature of the development of his country base on the real history and not their own interpretation. They must study history based on the concept of 'how it happens.' The role of Malaysia's political leadership is very important in uplifting Malaysians to live in peace and harmony. Malaysian political leadership must be sensitive and serious towards developing the Malaysian nation. Here, the nation includes the Malay, Chinese, Indian, Khadazan, Bajau, Dayak, and all ethnic groups in Malaysia. Bangsa Malaysia (The Malaysian Nation) can be born if the Malaysian political leadership has positive and responsible ideas and thoughts and adopts the slogan of 'Leadership by Example.' The narrow stream of political thought should not be allowed to smear Malaysian politics.

In a democratic country, the rights granted under the provisions of the Constitution should be exercised as best as possible by all parties. We should not let a single party take advantage of these provisions because the right belongs to every citizen. However, the authorized parties who implement the law sometimes act to restrict that right. Currently, Malaysia has gained its independence for more than 60 years; the question is whether the Malays or Bumiputeras have developed or on par with the other races in their own land. Or the Malays and Bumiputeras are still expecting a quota system and subsidies as before? (Mohamad, 1982). Malay supremacy has been questioned by many, especially the non-indigenous. The Malay supremacy should be seen as a legacy of Malay history that must be respected and cherished. The position of the Malay rulers should be revered because they are the heads of the States in Malaysia. Their position cannot be challenged by anyone because it is enshrined in the constitution. The question is, why should this matter be raised by the nonbumiputeras? Is it because they do not understand history, about the position of the sultanates, and more importantly, whether the Rulers are kings only to the Malays or to all Malaysians? Therefore, the implementation of history education as a core subject should be reviewed and strengthened. Thus, we need to have a steering committee towards dignifying and empowering the history subject at the school level which, when successfully implemented, the younger generation can know, understand and appreciate the history of Malaysia. A National Patriotism Academy (APN) should be developed to continue applying the spirit of patriotism and forming the Malaysian identity after leaving school. By knowing the history of the country, the new spirit of patriotism among the people can be realized. Independence Day is not just an annual event or anniversary celebration that is celebrated every year. Remember, history is a reminder and an element of national unity that must be performed continuously. This is consistent with the concept of lifelong learning. 
In tracing the history of the Malayan Union, on 1 March 1946 at Padang Kelab Sultan Sulaiman, Kuala Lumpur, there was a 10-year-old, Adnan Haji Osman with a message to all Malays with the words:

"... To the fathers, we call. Take a good step, defend our destiny! Defend our rights! God willing, when we grow up, we will commemorate all the fathers in the glorious history of the Malays..."

(Quoted from an interview with Prof Dato Dr. Nik Anuar Nik Mahmud)

The moral of the story, especially to the political leadership, is not to be too engrossed in politics and drunk with power without thinking about the people they rule. Remember that the leaders bear a big and heavy responsibility, which is to ensure the nation continues to progress in peace, harmony, and unity.

Dr. Burhanuddin al Helmy once suggested through his sacred words, "From the ruins of Malacca, we build an independent soul." The expression of these words reminds the Malays that the Malay race was once a powerful and famous people, in accordance with the Malay Sultanate Empire and majestic position. However, due to negligence, abuse of power, corruption, jealousy, and injustice, the power collapsed. Today the Malays are faced with the same situation. Taking heed of these words, the effort to develop ourselves, family, society, and the country requires an independent soul. A soul that is free from negative elements and static thoughts. This endeavor requires determination and diligence of hard work as there is no shortcut to development. Development needs to balance the demands of the Malays and Islam as its axis, which should not be dismissed. History has proven that the Malays were molded by Islam to become a glorious, bright, and eminent society. Islam will definitely uphold the pride and position of the Malays. Without Islam, the Malays would feel a loss of identity. Therefore, the question arises ... O the Malays, where are you from, where are you going...? Nevertheless, we must also remember the mandate of Tuan Guru Haji Abdullah Fahim, a figure that sets a sacred date for Malaya's independence, namely 31 August 1957 with the message:

"Remember O the Malays. If you fall again after 31 August 1957, believe me, you will not rise again until Judgment Day. "

(Message from Tuan Guru Haji Abdul Fahim)

The Malays, bumiputeras, and other Malaysians, as a whole, are splitting. The Malay and bumiputera political scenarios always seem to be in a splitting mode, each following their leaders. This phenomenon does not show that the Malays and bumiputeras are becoming increasingly powerful but exhibits smaller groups that struggle for power and the country's administration. The situation is fairly detrimental to the Malays. Today's political climate shows that history keeps repeating itself. But the political leadership of the Malays and bumiputeras, and their parties, do not want to learn from national history. Remember, history is a reminder.

\section{8 and 2013 Political Tsunami}

The political tsunami in the 2008 and 2013 general elections saw the Malays and Bumiputeras split repeating itself. However, the Malays and Bumiputeras remain the same, still fail to learn 
from history. Hence, not only the Malays but also the non-Malays question their integrity, honesty, and sincerity. If previously the Malays split into two groups, namely UMNO and PAS, now the Malays are splitting into three groups, namely UMNO, PAS, Parti Keadilan Rakyat Bersatu, Putera, Warisan, and other small Malay and bumiputera parties.

Thus, those in power should seriously and sincerely think about making changes for the survival of the Malays and Bumiputeras as well as the position of Islam in Malaysia. History also proved that Islam is a merchant religion. It was spread by trade and it is not impossible for it to go by trade as well. Therefore, it is feared that if Islam is not properly preserved, then it will once again trade or change to a nation that is willing to embrace it. By watching the historical development of Islam in India during the Mogul empire and study the position of Islam in the Malay Sultanate. Due to negligence/ taken for granted, Islam is no longer dominant until it destroyed the Malay Sultanate, which was once a powerful force in nearly all the islands of Archipelago. Thus, the question of Malay and bumiputera political leadership must ask is, where are we from, where are we going ...? So, Malay and Bumiputera leaders should sit down together and discuss, and set aside their own interests for the sake of religion, race, and nation. Must be taken seriously and tolerance for the sake of political survival and savival of Malays and Bumiputeras and the strengthening of the position of Islam in Malaysia. As Tan Sri Dato Seri Utama Dr Rais Yatim said:

"What do the Malays want next? This question needs to be answered immediately with action, no longer political rhetoric. Malay-Bumiputera seems too caught up with the ethnic issue so much so that they have forgotten to act as the Malays. "

He added:

"No matter what, as long as the Malays are Malays under Article 160 of the Federal Constitution, namely Muslims, normally speaks Malay and practice Malay customs - then the Malay agenda must be continued. When the political power of the Malays or survival is no longer practiced and repeated, the Malays will lose its direction. "

He firmly said:

"Islam, democracy and monarchy statehood, economic, political, cultural, Malay and knowledge through education are all part of the struggle of life that make up a Malay individual. When a nation forgets these basic things or lives in compromising situations and selfishness, then the environment will influence and weaken it."

(Harian, 2009).

The Malays and bumiputeras should be mindful and stop dreaming. They have to think that even if the political power is shaped by the Malay and bumiputera political leaderships, the Malays and bumiputeras should support and endorse it. The voraciousness of the Malay and bumiputera political leadership will cause the Malay power to become history. Indeed, political power is temporary and impermanent. Without awareness, it can disappear any time. Today, the position of the Malays and bumiputeras, and the position of Islam must be upheld. This time, the opportunity to defend Islam lies in the hands of the Malays, thus, it should not be wasted. Islam is not just rhetoric but a way of life that needs to be practiced and implemented. Without the sovereignty of Islam, there is nowhere for the Malays to go. 
Don't forget, today, Malaysia has moved forward as a plural society. Therefore, to survive, Malaysia must see polemic and political consensus among the races more positively and seriously. We must avoid the practice of narrow and extreme political culture and put national interests above everything else.

\section{Conclusion}

Undoubtedly, every Malaysian has the right to live in peace and harmony even though the country's population is multi-racial, multi-religious, and multi-cultural. Every citizen must understand each other to maintain unity and harmony in the country. Hence, take positive steps and adopt policies that build a spirit of unity. This can be achieved through the implementation of a national ideology, which is the Rukun Negara, that contains elements of peace, loyalty to the king and country, compliance with the constitution, and mutual respect and ethical behaviour (Zulhilmi \& Rohani, 2003). This matter is crucial because racial disputes and disagreements can lead to economic turmoil. This situation is not healthy for a developing country like Malaysia. If it left unchecked, it will result in an economic slowdown and threaten political stability. Foreign investors will turn to safer countries to invest. The economy will decline and eventually be paralyzed. If it is allowed to linger, Malaysia will enter the phase of a failed nation. Thus, we should learn from history of the collapsing of other countries to avoid falling into the same predicament. Remember that history is like a wheel, which, if it is left unchecked, it will eventually repeat.

\section{References}

Al Quran dan Terjemahannya. (2012). Mekah. Kerajaan Arab Saudi. Amanat Tuan Guru Haji Abdullah Fahim sempena Hari Kemerdekaan Persekutuan 31 Ogos 1957.

Carr, E. H. (1965). What is History? Pelican Book.

Keow, C. L. (2008). Falsafah dan Pendidikan Di Malaysia, Kuala Lumpur: Kumpulan Budiman. Muhamad, M. (1991). Wawasan 2020. Malaysia: Melangkah ke Hadapan. Biro

Tatanegara. Jabatan Perdana Menteri Malaysia. Kuala Lumpur.

Gawronski, D. V. (1975). History Meaning and Method, Philippine. Scott: Foresmen and Company.

Ensiklopedia Sejarah Dan Kebudayaan Melayu Jilid 1, 1997. Kuala Lumpur. Dewan Bahasa Dan Pustaka dan Kementerian Pendidikan Malaysia.

https://www.mstar.com.my/lokal/semasa/2009/04/03/najib-satu-malaysia-rakyatdidahulukan-pencapaian-diutamakan. https://www.moe.gov.my/menumedia/media-cetak/penerbitan/penyelidikan/1374laporan1pipp06to10/file.

Ibn-Khaldun. (1962). Filsafah Islam tentang Sedjarah. (trans: Charles Issawi) Jakarta: Tintamas.

Saat, I. (2005). Sejarah Sosial Masyarakat Malaysia. Shah Alam: KARISMA Publications.

Saat, I. (2007). Ilmu Sejarah, Antara Tradisi dan Moden. Shah Alam: KARISMA Publications.

Saat, I. (2009). Malaysia 1945-2000. Kuala Lumpur: Utusan Publications.

Saat, I., Jusoh, A., \& Abdullah, N. (2014). Sejarah Dalam Arus Kesedaran. Batu Pahat: Universiti Tun Hussein Onn Malaysia.

Hassan, S. A., \& Khairuldin, W. M. K. F. W. (2020). Research Design Based on Fatwa Making Process: An Exploratory Study. International Journal of Higher Education, 9(6), 241-246. 
Said, N. A., \& Khairuldin. (2017). Freedom of Speech in Islam and its Connection with Street Demonstrations. International Journal of Academic Research in Business and Social Sciences, 7(4), 122-129.

Ibrahim, I., \& Khairuldin. (2017). Fatwa as a Medium Da'wah: Studies on the Role of Mufti as a Preacher. International Journal of Academic Research in Business and Social Sciences, 7(4), 10-18.

Kachar, K. (1989). Kepimpinan Profesional Dalam Pendidikan. Kuala Lumpur: Teks Publishing.

Soong, K. K. (2007). May 13. Declassified Documents on the Malaysian Riots of 1969. Petaling Jaya: SUARAM Komunikasi.

Muhamad, M. (1982). Malay Dilemma. Singapura: Times Books.

Osman, M. T. (1988). Kebudayaan Melayu Dalam Beberapa Persoalan. Kuala Lumpur: Dewan Bahasa dan Pustaka.

Ghazali, M. R. (2001). Tema-tema Besar Pemikiran Muhamad Al Ghazali. https://ejournal.um.edu.my/index.php/afkar/article/view/6012/3726

Al-Kandahlawi, M. Y. (2019). Hayatush Shahabah, Kisah Kehidupan Para Sahabat Rasulullah. Jakarta: Qisthi Press.

Badaruddin, S. (2016). Masyarakat Madani dan Politik, ABIM \& Proses Demokrasi. Shah Alam: Institut Darul Ehsan.

Badaruddin, S., \& Shaharuddin, M. S. (2017). Islam, Demokrasi dan Politik Bangkangan di Malaysia. Shah Alam: Institut Darul Ehsan.

Badawi, A. A. (2006). Pembangunan Modal Insan. Kuala Lumpur. Jabatan Perdana Menteri.

Mahmud, N. A. N. (2006). [Interview].

Paidi, Z., \& Ghani, R. A. (2003). Pendidikan Negara Bangsa. Kuala Lumpur: PTS Publications \& Distributors. 